\title{
'Me old mate Victa': Technological change and society in post-World War Two Australia
}

\author{
M. L. Crespo \\ School of Social Sciences, Haydon-Allen Building, The Australian National University, Acton ACT 0200, \\ Canberra, Australia
}

Way back in the early days

Mowin' kept us fit and lithe

Coz the only way to do it

Was to swing a flaming scythe

Until some bright spark somewhere

Said, "Now this'll be a goer!"

And came up with that curse of kids

The horrible push mower

But then one day Merv Richardson

An engineer from Adelaide

Showed the world a better way

To spin a mowing blade

He took a two stroke engine

Made a peach tin petrol tank

Slapped it onto four old wheels

And gave the rope a yank

And so, in 1952

The Victa mower was born

And ever since that time has turned

Australian grass to lawn

Victa's become an institution

The sound of our weekend

Though I curse those early starters

If me sore heads on the mend

Nothin's worse than Sat'dy mornin'

After Friday on the tiles

When the Victas wake up with the crows

And you can hear them roar for miles

Or when your mates have come for lunch

And you've just lit the barby

And the Victas on both sides of you

Start a local mowing derby!

- Brian Doyle excerpt from 'Me Old Mate Victa'

${ }^{1}$ Brian Doyle, 'Me Old Mate Victa'

$<$ http://www.abc.net.au/rural/telegraph/poetry/stories/s438532.htm>, first accessed on $30^{\text {th }}$ September, 2008 
Do technologies arrive "just in time" to cater to some particular market? Brain Doyle indicates so in his poem Me Old Mate Victa where the curse of the push mower was suddenly evaporated with Merv Richardson's invention of the two-stroke engine (commonly known as the Victa Mower). Peter Timms, in his history of the Australian suburban garden, argues similarly, stating that 'the Victa was just what home gardeners had been waiting for'. ${ }^{1}$ While arguments such as these prove useful in developing a narrative or story of technology in Australia, they do not address the issue of technological change and its relationship with society. ${ }^{1}$ In presenting this history of the lawnmower I want to particularly highlight technology as something that does not simply evolve to perform some function 'in a better way'; nor is society passive in 'waiting' for technology to arrive. The history of the lawnmower in the context of Australian society, predominantly in the period immediately following the Second World War, demonstrates how adaptation and entrenchment of values takes place in a period of change

Determinism - that is defining cause as something existing outside the idea in focus - in historical analysis seems an easy method to turn to, if anything, because it simplifies the story that is portrayed. Smith articulates it best when he says:

\section{"The frustration we experience with technological determinism and technocratic thinking is as much with ourselves as it is with the larger societies in which we live. As moths to flames, we find ourselves continually attracted to its alluring but dangerous glow."}

Therefore, before embarking on 'a history of the lawnmower', it is necessary to deliver a frame of reference that does not fall in the trap of technological determinism. This, I present in two segments. Firstly, technology is an extension of self: a material expression of human desire to perform a task. Such a conception stems from Mazlish and his exploration of how society is in the process of reconciling the discontinuity between humans and machines. ${ }^{2}$ To demonstrate: a rock is perceived as an object without direct relationship to an individual. However, if I were to pick up the rock and throw it at someone, one might relabel the rock as a weapon - as a technology. The action placed on the object, changing the relationship between the rock and myself, in this case for the purpose for my desire, is what defines it as technology.

\footnotetext{
${ }^{1}$ Merritt Roe Smith, 'Technological Determinism in American Culture', Does technology drive history?: The Dilemma of Technological Determinism, Merritt Roe Smith and Leo Marx (eds.), MIT Press, Cambridge, 1994, p. 35

${ }^{2}$ Bruce Mazlish, The Fourth Discontinuity: The Coevolution of Humans and Machines, Yale University Press, New Haven, 1993 pp. 5-6
}

However, there is also a collective acknowledgement of technology that has to be addressed. This is the second portion of my definition and stems from discussions made by Heilbroneir, who argues that 'technological change must be compatible with existing social conditions, ${ }^{3}$. The continuum between humans and their technologies is conditional on the environments, or more formally on the institutional arrangements, of their society. This definition will be demonstrated through an exploration into the history of lawnmower. Particularly, I want to focus my attention to the re-conceptualisation of the lawnmower in the period after the Second World War in Australia. Why does this re-conceptualisation take place? I will argue that there are institutional arrangements in Australia's cultural history that converge to a point where an invention is given legitimacy through desire to serve a purpose.

\section{NO MORE WAITING: A USERS HISTORY OF THE LAWNMOWER?}

Technological change centres on the recognition that there are available resources to (re)develop tools to perform particular actions. A common example is Edison's knowledge of the various materials that could be made available to sustain illumination of an electric current. ${ }^{4}$ Similarly the development of the lawnmower stems from the realisation that mechanisation can be applied to the action of cutting

\footnotetext{
${ }^{3}$ Robert L. Heilbronier, 'Do Machines Make History?', Does technology drive history?: The Dilemma of Technological Determinism, Merritt Roe Smith and Leo Marx (eds.), MIT Press, Cambridge, 1994, p. 63 ${ }^{4}$ Robert D. Fridel, and Paul Israel, and Bernard S. Finn, 'Afterword', Edison's electric light : biography of an invention, Rutgers University Press, New Brunswick, 1986 , p. 225
} 
grass; the knowledge is there, it is simply the matter of the adaptation. No real development of the French agricultural implement, the scythe, had been made since its inception in the mid-seventeenth century. However, during the eighteenth century, large British estates began to develop what were known as 'the natural gardens'. ${ }^{5}$ This was then followed by the cultivation of common land into parkland during the nineteenth century and is concurrent with the development of sporting grounds. ${ }^{6}$ Thus, a formation of the tradition of maintaining short grass for aesthetic and sporting purposes is popularised and it is from this context that the most significant change in the action of cutting grass is made.

Edwin Beard Budding, a freelance Engineer working in the Gloucestershire area, found his inspiration for the first lawnmower from a cylindrical rotary blade that was used to cut cloth at a local mill, sometime in 1830 . The patent for the first lawn mower was granted on the $25^{\text {th }}$ of October 1830 and its motivation and application is stated in the patent:

"A new combination and application of machinery for the purpose of cropping or shearing the vegetable surfaces of lawns, grass-plats, and pleasure grounds, constituting of a machine which may be used with the advantage instead of a scythe for that purpose ...grass growing in the shade too weak to stand against the scythe to cut, may be cut by my machine as closely as required, and the eye will never be offended by those circular scars, inequalities and bare places so commonly made by the best mowers with the scythe, and which continues visible for several days. Country gentlemen may find in using my machine themselves and amusing, useful and healthy." 7

There are notable aspects of Budding's design that have not changed; the handles to push the mower, or the side-wheels used to direct the rotating blade forward for example. However, these early conceptions were a great deal more cumbersome in comparison to what one may think of as the contemporary equivalent push-mower. Early versions were often made from cast-iron, and required a pull (often by a pony, donkey or horse) at

\footnotetext{
${ }^{5}$ Timms p. 117

${ }^{6}$ David G. Halford, Old lawn mowers, Shire, Princes Risborough, 1982, p. 3

${ }^{7}$ Ibid., p. 4
}

the same time as a push (preferably performed by the gardener). These early designs sought to cater to the conditions that were placed upon it during the nineteenth century.

The push-mower, for single person use, is popularised from the patents of Follows and Bate in 1869 and comes to be known as the side-wheel lawnmower. ${ }^{8}$ The reason why this particular model of the mower is developed though is not because of simple evolution of technology, but as a result of the growth of detached and semi-detached housing during the later half of the nineteenth century in Britain, the United States, and of course in Australia. Suburbia acts as firstly as a British phenomenon, in reaction to rapid industrialisation of its economy, which in turn, develops a new affluent middle-class that cultivated its own values. These emerging traditions were espoused in the presentation of their neighbourhoods (located outside the city centre) in which the garden became central. ${ }^{9}$ The United States and Australia, similar in their economic development, follow suite and are indeed able to nourish the idea-both having wide open spaces for building and relatively egalitarian societies. ${ }^{10} \mathrm{In}$ Australia, companies such as Crowe Engineering Works, Clyde Industries, as well as British manufacturing subsidiaries (Qualcast and Shanks) produced manual cutters that would help entrench the idea of 'maintaining the lawn' throughout the 1930s and 40s. ${ }^{11}$ Powered mowers, were available by the 1940s in Australia - the development of the petrol engine mowers had first being sold to the Cadbury Brothers for their Bournville sports ground in $1902^{12}$-however, they were again cumbersome machines that were much too unwieldily for the average household to maintain. ${ }^{13}$ However, they did suit relatively well for a mower business, and indeed this is where this history finds Victa Mowers in 1950; son Garry and father Mervyn, trying to load

\footnotetext{
${ }^{8}$ Ibid., p. 13

${ }^{9}$ Timms, pp. $23-4$, p. 32

${ }^{10}$ Ibid., p. 19

${ }^{11}$ Cockington, James, 'Pushed for time', The Age,

December 5, 2007,

$<$ http://www.theage.com.au/news/planning/pushed-fortime/2007/12/03/1196530579050.html $>$, first accessed on $4^{\text {th }}$ of October, 2008

${ }^{12}$ Halford, p. 19

${ }^{13}$ Brian Carroll, Australian Made: Success Stories in Australian Manufacturing Since 1937, Institution of Production Engineers Australian Council, Parkville, 1987, p. 92
} 
such a powered lawnmower into the sidecar of Garry's motorbike. ${ }^{14}$

Of course the history of technology can never be as simple as a single inventor, cast with an idea. Mervyn Victor Richardson was not actually the inventor of the two-stroke rotary engine driven mower as is commonly mythologised in Australian history. In fact, the first patent of a rotary blade, horizontally spun by a vertical motor is said to have been issued in Great Britain on $29^{\text {th }}$ of February 1932 to a David Hamilton Cockburn. ${ }^{15}$ However, even this is disputable: an earlier patent exists in the US was issued to Joshphus Miller of Louisville, Kentucky on The $10^{\text {th }}$ of November 1931. ${ }^{16}$ Richardson cannot even be attributed with the first conceptualisation of this motorised horizontal blade in Australia; this honour falls to Lawrence Hall, from Adelaide, who in 1948 developed a rotary blade lawn-mower to cut his parents lawn. Hall's lawnmower, named 'Mowhall' used his experience as a boat engine builder to develop a petrol-driven prototype, however, it was limited in its usability; needing two people to push and pull the contraption across the lawn. ${ }^{17}$ It was in 1948 that Richardson saw the 'Mowhall' in demonstration and subsequently turned his attention to developing a similar concept that would be as light and inexpensive as the vacuum cleaners in most homes

\footnotetext{
${ }^{14}$ Vivian Encel, Australian genius, 50 Great Ideas, Atrand Pty Ltd, Crows Nest, 1988, p. 70

${ }^{15}<$ http://www.wikipatents.com/gb/0385473.html > , first accessed on $4^{\text {th }}$ of October, 2008 holds a copy of the patent GB 385473, the patent is indicated by IP Australia to be the earlier design see

$<$ www.ipaustralia.gov.au/patents/ex_victa.shtml $>$, first accessed on $7^{\text {th }}$ September, 2008

${ }^{16}$ US 1831681 . To see a copy of this patent see Google Patents:

$<$ http://www.google.com/patents?id=Pn9OAAAAEBAJ\& $\mathrm{pg}=\mathrm{PA} 1 \& \mathrm{dq}=\mathrm{US}+$ patent $+1,831,681 \&$ source $=$ gbs_selecte d_pages\&cad $=0 \_1 \#$ PPA3,M1 $>$, first accessed on $4^{\text {th }}$ October, 2008. Intellectual Property and Internet Barrister Chambers Design Chambers, in Wimbledon, UK have noted in their research that 'Unlike the Rotoscythe [the British patent], the Louisville mower did not feature any grass collection system nor were the cutting blades completely surrounded by the deck (or otherwise) of the machine' for more information see:

$<$ http://www.designchambers.com/electra/index.htm\#Rot oscytheFirst?>, first accessed on $4^{\text {th }}$ October, 2008.

${ }^{17}$ Australian Academy of Technological Sciences and Engineering \& The Power House Museum, 'Sell Advertise and Inform People', The Innovation Cycle $<$ http://www.powerhousemuseum.com/australia_innovate $\mathrm{s} /$ sell.html $>$, first accessed on $4^{\text {th }}$ of October, 2008
}

at the time. ${ }^{18}$ As the Australian Dictionary of Biography presents it, once Richardson decided to use a Villers engine in August 1952 it only took Richardson a couple of hours to draw up a new design that turned the motor on its side (varying it from the 1930s designs) and set two blades, rotating horizontally on the frame of a billy-cart. ${ }^{19}$ His wife, Vera, was given the first honour of its use, testing it on a patch of overgrown grass in the backyard of their Concord home in Sydney. ${ }^{20}$ Within two years, Richardson had given up his work as an Engineer salesman to run Victa Mowers and within four years, the company established its factory on Parramatta Road, within 10 years, Victa Mowers had established a production line that could produce a mower a minute. ${ }^{21}$

Therefore, we can see that numerous inventions are associated with the lawnmower, and like in so many histories of technologies, such as the zipper, or the light bulb, there is not one, but many inventors, each bringing particular insight. However, what succeeds in each period and environment is determined by what continues to suit the needs of the society. Richardson is able to discover an approach to conceptualising the lawnmower that would meet the desires of gardening during the 1950s in Australia - to make it inexpensive and easy to cut ones grass. These conditions are different in the case of the British history of the lawnmower, which could equally focus on the development of the first cylindrical blade mowers for large estates as it could on the development of the rotary blade mower. However, it is a collective acknowledgement of a particular invention that gives licence to a specific 'technology' that represents that tool which is used to perform that particular action. To better understand how this process occurs with the lawnmower in post war Australia, I will next turn my attention to further exploring the historical conditions of Australian suburbsanism that leads to this collective acknowledgement of Victa as 'Australia's top selling mower'. ${ }^{22}$

\footnotetext{
${ }^{18}$ Richard V. Wood, 'Richardson, Mervyn Victor (1893 1972)', Australian Dictionary of Biography, Volume 16, Melbourne University Press, 2002, pp.84-85 and Brian Carroll, 'This Was Australia: Mow and Ye Shall...', The Sun (Sydney), $17^{\text {th }}$ July 1984, p. 40

${ }^{19}$ Wood, pp. 84-85

${ }^{20}$ Encel, p.70 and Carroll, 'This Was Australia: Mow and

Ye Shall...', p. 40

${ }^{21}$ Carroll, p. 92

${ }^{22}$ This caption was part of Victa's 1959 Advertising campaign, see Australian Academy of Technological Sciences and Engineering \& The Power House Museum,
} 


\section{A BETTER WAY?: CHANGE AND TECHNOLOGICAL HISTORY}

Those who have written of the lawnmower in Australia, for example Brain Carroll, Vivian Encel, as well as the bush poet Brain Doyle, have assumed that application of mechanisation to the cutting of grass has been a natural advancement. ${ }^{23}$ However, there are other commentators who are willing to be more nuanced in their approach to examining this impact. Peter Timms, for example, delivers important insight when he argues that 'the cylinder mower...has almost entirely given way to the quicker, more convenient rotary'. ${ }^{24}$ Was the lawnmower improved upon or did it continue to change to satisfy our desires? Thus far, this essay has argued the former-efficiency is a desire that is created to fit a societal position or ideology created. To comment on whether this is progress forwards or not is to comment on another theoretical argument. Therefore, in analysing historically significant technological change in society, we have to be wary of the potential to blur the lines between change and progress. As such, the focus of this essay will now turn to the exploration of the relationship between the technical changes to the lawnmower and changes in Australian society after the Second World War.

Overcoming constraints is one of the more dominant factors driving technological change. However, more important is the definition of that constraint in the first place. Budding's definition of his constraint was driven by cultural conditioning of the idea of a 'natural garden', which by the 1830s was demanding quality and consistency in the maintenance of lawns. Halford's history of the lawnmower, Old Lawn Mowers, has many examples of lawnmower inventions where the constraint has not been properly identified. James Sunder's and Alexander Shanks' steam-powered lawnmowers, for example, appear as obsolete in 1900 in the face of the new petrol driven lawnmowers. ${ }^{25}$ Heilbroner argues that what is perceived as advancement in technology "not only must be congruent with the surrounding technology but must also be compatible with the existing economic and other institutions of

\footnotetext{
'Sell - Advertise and Inform People', The Innovation Cycle

$<$ http://www.powerhousemuseum.com/australia_innovate s/sell.html $>$

${ }^{23}$ Carroll, p. 92 and Encel, p. 70

${ }^{24}$ Timms, p. 112

${ }^{25}$ Halford, pp. 16-17
}

society'. ${ }^{26}$ Therefore definition of the constraint by Mervyn Richardson in 1952 comes from his understanding of institutional arrangements.

Graeme Davison describes four broad periods that converge to form the basis of suburbanism in Australia. First is that of early colonial development, starting with Arthur Phillip, of the building of semidetached and detached housing in Sydney. ${ }^{27}$ This method of housing was then subsequently expanded with the arrival of free immigrants during the 1830s and $40 \mathrm{~s}$ and then entrenched by a sustained period of prosperity during the $1860 \mathrm{~s} .{ }^{28}$ Conditioning of this culture of housing was promoted uniformly across the colonies, as a result of weak local councils and strong paternalistic colonial governments, particularly in New South Wales. ${ }^{29}$ However, as Alastair Greig has most comprehensively noted, it was the housing shortage of the post World War Two period that instigated not only large amounts of government assistance for housing, but also allowed for the infusion of modernist ideas into house design and planning. ${ }^{30}$ Phillip Scranton, as an historian reminds us that individuals act both in and upon institutions (a family, a firm, a government), and they embody, realize, and reproduce those institutions through their daily activity'. ${ }^{31}$ As such the late 1940s and $1950 \mathrm{~s}$ act as a period in Australian history where existing values and traditions, such as the push mower on the weekend, are adapted and reshaped to reflect modernist

\footnotetext{
${ }^{26}$ Heilbroner, p. 63

${ }^{27}$ Graeme Davison, The past and future of the Australian suburb, R.C. Coles (series ed.) Urban Research Program, Research School of Social Sciences, Australian National University, Canberra, 1993, p.5, see also Alan Gilbert, 'The Roots of Anti-Suburbanism in Australia' Australian cultural history, S.L. Goldberg and F.B. Smith (eds.) Cambridge University Press, Melbourne, 1989, p. 33

${ }^{28}$ Davison, p. 5

${ }^{29}$ Ibid., p.5 see also Alan Atkinson, 'Time, Place and Paternalism: Early Conservative Thinking in New South Wales', Australian Historical Studies, 23/90, April 1988, pp. 1-18, for discussion of colonial paternalism in New South Wales, discussion by Geoffrey Bolton, Spoils and Spoilers: Australians Make Their Environment, George Allen \& Unwin, Sydney, p.68 on the export development of the colonies which resulted in weak small, rural towns in comparison to the developing cities.

${ }^{30}$ Alastair Whyte Greig, and Australian National University, Home Magazines and Modernist Dreams: Designing the 1950s House, Urban Research Program, Research School of Social Sciences, Australian National University, Canberra, 1995, p. 1

${ }^{31}$ Scranton, p. 152
} 
assumptions, such as the re-conceptualisation of the lawnmower into a petrol driven, commercial product.

The development of suburbanism in Australia, throughout the late 1940s is evident in Mervyn Richardson's re-conceptualisation of the lawnmower: as was noted previously in this essay, he asked why the lawnmower was not as light and manoeuvrable as other domestic products such as the vacuum cleaner. However, this influence is not simply the environment, in which the Victa Mower is born, but also the environment, in which Victa Mowers Company used to entrench their products into the commercial space of $1950 \mathrm{~s}$ and $1960 \mathrm{~s}$ Australia. Victa Mowers advertising strategies were typical of their style in that they used psychologybased advertisements that sought to idealize the suburban dream. ${ }^{32}$ The slogan from Victa's 1959 advertising campaign 'Turn your grass into lawn' is classic in its appeal to symbolism that the lawn plays portraying the public front garden of the typical suburban home. ${ }^{33}$ However, Victa Mowers went well beyond the traditional mould in its advertising. Richardson began demonstrating his Victa mowers during the summer of 1952 as they came off the production line in his garage. This technique continued throughout the 1950s, 1960s and 1970s with staff devoted exclusively to travelling to schools, hardware stores, and department stores to demonstrate how to use a Victa lawnmower. ${ }^{34}$ The result was that Victa Mowers has consistently portrayed itself as the technological innovator in lawn-mowing and Australian society has as a result acknowledged it as representing lawn-mowing 'technology'.

\footnotetext{
${ }^{32}$ For discussion of psychology-based advertisement and portrayal of nationalist ideals, see Smith, p. 13

${ }^{33}$ On Victa Mowers advertising see Australian Academy of Technological Sciences and Engineering \& The Power House Museum, 'Sell - Advertise and Inform People', The Innovation Cycle

$<$ http://www.powerhousemuseum.com/australia_innovate s/sell.html $>$, the symbolism of the lawn as a public space can be read in Peter Timms, p.64-66 and John Fiske and Bob Hodge and Graeme Turner, Myths of $\mathrm{Oz}$ : reading Australian popular culture, Allen \& Unwin, Sydney, 1987, p. 30

${ }^{34}$ Australian Academy of Technological Sciences and Engineering \& The Power House Museum, 'Sell Advertise and Inform People', The Innovation Cycle $<$ http://www.powerhousemuseum.com/australia_innovate s/sell.html>
}

\section{CONCLUDING THOUGHTS}

The visual created by the 'mower symphony' of the 2000 Olympic opening ceremony, with hundreds of keen performers pushing model Victa mowers and weaving themselves into the Olympic rings formation, must have seemed truly bizarre to the millions watching around the world. Nevertheless, to many of viewers who had had any association with the concept of Australian suburbia it spoke in volumes. The Victa Lawnmower represents how the history of one invention in a specific societal context can be collectively legitimated as the history of an entire technology. The lawnmower in Australia represents a desire, created by the conditions of housing shortage in combination with the existing traditions of subrbanism established in colonial Australia, to find a convenient tool to perform the task of mowing the lawn. The Victa Lawnmower, despite not having been the original invention, was, and still is, acknowledged as the technology that represents lawn mowing in Australia. This history of the lawnmower has also demonstrated that historians of technology should be careful in articulating the theoretical framework from which they aim to work from. There is great potential for well-developed technological histories to give important insights into the societies of the past, which in turn can offer up insight into the operation of societies today.

\section{ACKNOWLEDGMENTS}

I am most grateful to Dr. John Knott for his helpful comments and suggestions in particular, and intellectual support in general. I would also like to acknowledge the assistance of Dr. Alastair Greig for stimulating thought on argument, strength and structure. 


\section{REFERENCES}

Archer, John, Building a Nation: A History of the Australian House, Collins, Sydney, 1987

Atkinson, Alan, 'Time, Place and Paternalism: Early Conservative Thinking in New South Wales', Australian Historical Studies, 23/90, April 1988, pp. 1-18

Australian Academy of Technological Sciences and Engineering \& The Power House Museum, 'Sell Advertise and Inform People', The Innovation Cycle $<$ http://www.powerhousemuseum.com/australia_innovate s/sell.html $>$, first accessed on 30th September, 2008

Bolton, Geoffrey, Spoils and Spoilers: Australians Make Their Environment, George Allen \& Unwin, Sydney, 1981

Boyd, Robin, The Australian ugliness, Cheshire, Melbourne, 1960

Carroll, Brian, Australian Made: Success Stories in Australian Manufacturing Since 1937, Institution of Production Engineers Australian Council, Parkville, 1987, pp. 92-93

-------------, 'This Was Australia: Mow and Ye Shall...' The Sun (Sydney), $17^{\text {th }}$ July 1984, p. 40

Cockburn, David Hamilton, 'Improvements in machines for cutting grass and the like', Patent GB 385473 $<$ http://www.wikipatents.com/gb/0385473.html>, first accessed on $4^{\text {th }}$ of October, 2008

Cockington, James, 'Pushed for time', The Age, December 5, 2007,

$<$ http://www.theage.com.au/news/planning/pushed-fortime $/ 2007 / 12 / 03 / 1196530579050$. html?page $=2>$, first accessed $4^{\text {th }}$ October, 2008

Davison, Graeme, The past and future of the Australian suburb, R.C. Coles (series ed.) Urban Research Program, Research School of Social Sciences, Australian National University, Canberra, 1993

Design Chambers, 'Old Electric Lawn Mowers' $<$ http://www.designchambers.com/electra/index.htm\#Rot oscytheFirst?>, first accessed on $4^{\text {th }}$ of October, 2008.

Doyle, Brian, Me Old Mate Victa,

$<$ http://www.abc.net.au/rural/telegraph/poetry/stories/s43 8532.htm $>$, first accessed on $30^{\text {th }}$ September, 2008.

Encel, Vivien, Australian genius, 50 Great Ideas, Atrand Pty Ltd, Crows Nest, 1988.
Fiske, John and Hodge, Bob and Turner, Graeme, Myths of $\mathrm{Oz}$ : reading Australian popular culture, Allen \& Unwin, Sydney, 1987.

Friedel, Robert D. and Israel, Paul. and Finn, Bernard S., 'Afterword', Edison's electric light : biography of an invention, Rutgers University Press, New Brunswick, 1986, pp. 223-232.

Gilbert, Alan, 'The Roots of Anti-Suburbanism in Australia' Australian cultural history, S.L. Goldberg and F.B. Smith (eds.) Cambridge University Press, Melbourne, 1989.

Greig, Alastair Whyte, and Australian National University, Home Magazines and Modernist Dreams: Designing the 1950s House, Urban Research Program, Research School of Social Sciences, Australian National University, Canberra, 1995.

Halford, David G. Old lawn mowers, Shire, Princes Risborough, 1982.

Heilbroner, Robert L. 'Do Machines Make History?', Does technology drive history?: The Dilemma of Technological Determinism, Merritt Roe Smith and Leo Marx (eds.), MIT Press, Cambridge, 1994, pp. 53-65.

Holmes, Katie "'In Spite of it all the garden still stands": Gardens, Landscape and Cultural History' Cultural history in Australia, Hsu-Ming Teo and Richard White (eds.) UNSW Press, Sydney, 2003, pp. 172-185.

IP Australia, 'Patent Example: Victa Lawn Mower', $<$ http://www.ipaustralia.gov.au/patents/ex_victa.shtml $>$, first accessed on $7^{\text {th }}$ of September, 2008.

Kociumbas, Jan, The Oxford history of Australia, Volume 2, 1770-1860: Possessions Oxford University Press, Melbourne, 1995.

Marx, Leo, and Smith, Merritt Roe, 'Introduction' Does technology drive history?: The Dilemma of Technological Determinism, Merritt Roe Smith and Leo Marx (eds.), MIT Press, Cambridge, 1994, pp. ix- xvii.

Mazlish, Bruce, The Fourth Discontinuity: The Coevolution of Humans and Machines, Yale University Press, New Haven, 1993.

Miller, Josephus, 'Edge Trimming and Mowing Machine', Patent US 1831681,

$<$ http://www.google.com/patents?id=Pn9OAAAAEBAJ\& pg $=\mathrm{PA} 1 \& \mathrm{dq}=\mathrm{US}+$ patent $+1,831,681 \&$ source $=$ gbs_selecte 
d_pages\&cad $=0 \_1 \#$ PPA3,M1 $>$, first accessed on $4^{\text {th }}$ of October, 2008.

Renew, Robert, and Powerhouse Museum, Making It: Innovation and Success in Australia's Industries, Powerhouse Pub., Haymarket, 1993.

Richardson, Garry, Education For Freedom: Blueprint for a Human-Centered School Gavemer Foundation, Sydney, 1985.

Scranton, Phillip, 'Determinacy and Indeterminacy in the History of Technology', Does technology drive history?: The Dilemma of Technological Determinism, Merritt Roe Smith and Leo Marx (eds.), MIT Press, Cambridge, 1994, pp. 143-168.

Schreuder, D. M. and Ward, Stuart, 'Introduction', Australia's Empire Deryck M. Schreuder and Stuart Ward (eds.), Oxford University Press, Oxford, 2008.
Smith, Merritt Roe, 'Technological Determinism in American Culture', Does technology drive history?: The Dilemma of Technological Determinism, Merritt Roe Smith and Leo Marx (eds.), MIT Press, Cambridge, 1994, pp. 1-35.

Timms, Peter, Australia's Quarter Acre: The Story of the Ordinary Suburban Garden, Miegunyah Press, Carlton, 2006.

Todd, Jan Colonial Technology: Science and the transfer of innovation to Australia, Cambridge University Press, Cambridge, 1995.

Wakely, Mark, Dream Home, Allen \& Unwin, Crows Nest, 2003.

Wood, Richard V. 'Richardson, Mervyn Victor (18931972)', Australian Dictionary of Biography, Volume 16, Melbourne University Press, 2002, pp. 84-85. 